\title{
Factors Affecting Blood Pressure Control in Hypertension Patients and Their Social Adaptation
}

\section{Hipertansiyon Hastalarında Tansiyon Kontrolüne Etki Eden Faktörler ve Sosyal Uyum}

\author{
Merve Betül Özdemir, (İsmail Arslan, Nuri Şengüleroğlu, @izzet Fidancı, \\ DDuygu Yengil Taci, $\mathbb{D}$ Oğuz Tekin
}

Ankara Training and Research Hospital, Department of Family Medicine, Ankara, Turkey

\begin{abstract}
Aim: In this research, we aimed to analyze the factors affecting the control of blood pressure and social adaptation in hypertensive patients.

Material and Method: Our study was conducted with 100 hypertensive patients in Ankara Training and Research Hospital Family Medicine Polyclinics between December 2015 and March 2016. Five-day blood pressure follow-up, socio-demographic characteristics and "Fatih Social Tendencies Scale" questionnaire data of the patients were recorded. 5-day blood pressure follow-up of the patients was performed.

Results: A total of 100 individuals including 48 (48\%) male and 52 (52\%) female patients were included in the study. In our research, physical activity, regular exercise, being on diet, smoking, regular doctor check, medication compliance, marital status, years of education, regular book reading, working status and monthly income were found to be effective in blood pressure control."Social Adaptation", "Avoidance of Substance", "Avoidance of Violence", "Family Status" and "Economic Status" among social tendency factors were found to be better in patients with blood pressure under control.

Conclusion: In blood pressure follow-up, the lifestyle characteristics of the patient should be questioned and taken into consideration. Questioning psychological factors such as social adaptation and providing support through the provision of necessary information and education to the patient will make a great contribution to the patients in terms of blood pressure control.
\end{abstract}

Keywords: Hypertension, social adjustment, follow-up studies
Öz

Amaç: Çalışmamızda, hipertansiyon hastalarının tansiyonlarının kontrolüne etki eden faktörleri ve sosyal uyumu değerlendirmeyi amaçladık.

Gereç ve Yöntem: Çalışmamız Aralık 2015-Mart 2016 tarihleri arasında Ankara Eğitim ve Araştırma Hastanesi Aile Hekimliği Polikliniklerinde 100 hipertansif hasta ile yapıldı. Hastaların beş günlük tansiyon takibi, sosyodemografik özellikleri ve "Fatih Sosyal Eğilimler Ölçeği" anket verileri kaydedildi. Hastaların 5 günlük tansiyon takipleri yapıldı.

Bulgular: Katılımcıların 48 (\%48) tanesi erkek; 52 (\%52) tanesi kadın olup toplamda 100 kişi çalışmamıza dahil edildi. Çalışmamızda fiziksel aktiflik, düzenli egzersiz, diyetine dikkat etme, sigara kullanımı, doktora düzenli gitme, ilaçlarını düzenli kullanma, evli olma, eğitim yılı, düzenli kitap okuma, çalışma durumu ve aylık gelir düzeyi tansiyon kontrolünde etkili olduğu bulundu. Sosyal eğilim faktörlerinden "Sosyal Uyum", "Maddeden Kaçınma", "Şiddetten Kaçınma", "Aile Statüsü"ve "Ekonomik Durum" faktörlerinin tansiyonları kontrol altında olan hastalarda daha iyi olduğu gözlendi.

Sonuç: Tansiyon takibinde hastanın yaşam tarzı özelliklerinin sorgulanması ve göz önüne alınması, sosyal uyum gibi psikolojik faktörlerin sorgulanması ve bu konuda gerekli bilgi ve eğitimin hastaya verilmesi ile destek sağlanması tansiyon kontrolü açısından hastalara büyük katkı sağlayacaktır.

Anahtar Kelimeler: Hipertansiyon, sosyal uyum, takip çalışmaları 


\section{INTRODUCTION}

As one of the preventable global death causes, hypertension constitutes a prevailing and treatable risk factor. Among chronic diseases, it is a leading cause of the referrals to Family Medicine polyclinics. Differences are present between the hypertension guidelines before and after 2017 and the current classification defined a decrease from $25 \%$ to $18 \%$ in hypertension prevalence in patients without cardiovascular disease. ${ }^{[1]}$ There is an estimated number of 15-16 million hypertension patients in our country. ${ }^{[2]}$ Epidemiological studies reported a HT prevalence of $31.8-41.7 \%$ in our country. ${ }^{[3,4]}$

Blood pressure follow-up and decreased referral for doctor control in hypertension patients using medication are generally caused by their trust on medication use and considering this, the importance of blood pressure measurements should be explained satisfactorily to the patients. ${ }^{[1-4]}$

Our aim in this study was to evaluate the effects of the sociocultural and economic condition of patients and the effect of detailed clinical evaluation by primary care physicians in HT patients based on social adaptation condition in HT control.

\section{MATERIAL AND METHOD}

Our study is a cross-sectional study with an analytic pattern. Consent no 5166 was taken from Ankara Training and Research Hospital Ethics Board in the meeting no 0617 dated 11.11.2015 before starting our study. The examining doctor applied face-to-face survey on 100 consenting patients who referred to Ankara Training and Research Hospital Family Medicine polyclinics between 01 December 2015 and 31 March 2016. No sampling calculation was performed and all patients meeting the study criteria and giving consent between the mentioned dates were included in the study.

Sociodemographic characteristics and Fatih Social Tendencies scale was applied to the participating patients. Stress condition, presence of any chronic diseases, blood pressure checking interval, control interval and the referred health institutions were asked in addition to the smoking, exercising and diet application conditions. Five-day blood pressure follow-ups (systolic and diastolic blood pressure measurements at the same hours in the morning and evening) were demanded from the patients. Mean blood pressure was calculated through taking the arithmetic mean of the data acquired during five-day follow-up. Patients who had blood pressure measuring device at home and had blood pressure measuring device for less than two years were included in the study. A year limit was determined for blood pressure device for the safety of blood pressure measurements.

The condition of blood pressure being under control was regulated based on JNC 8; target systolic BP should be below $150 \mathrm{mmHg}$ and diastolic BP should be below $90 \mathrm{mmHg}$ in individuals aged $\geq 60$ while the systolic BP level should be below $140 \mathrm{mmHg}$ and diastolic BP level should be below 90 $\mathrm{mmHg}$ in individuals under 60 years of age based on JNC $8^{[5]}$

\section{Fatih Social Tendencies Scale}

We conducted Fatih Social Tendencies Scale developed by Tekin et al to evaluate the social tendencies of the participants (6 factors 22 questions, with five point Likert scale (I.Totally disagree, II.Disagree, III.Neutral, IV.Somewhat agree, V.Certainly agree). Scoring of the sentences negatively related to the factor was performed through subtracting from 6. Cronbach's Alpha value for the general reliability of the scale is 0.794 (Corrected 0.811) and the scale is highly reliable based on its corrected value. The Factors of the scale are Social Adaptation (SA), Tendency of Avoiding Substance (AS), Tendency of Avoiding Violence (AV), Economic Status (ES), Family Status (FS) and Targets and Ideals (TI). The scores of the sub-groups are evaluated separately and the scaling of the related factor is evaluated as "higher" as the score increases. Fatih Social Tendencies Scale can be used to research the effects of descriptive characteristics on social tendencies. ${ }^{[6]}$

\section{Statistical Analysis}

Data were evaluated through entering in SPSS statistics package program version 16.0. After determining the factors affecting the blood pressure control through Logistic Regression Analysis, the effect direction of the factors was calculated through Chi-Square Test and Comparison Analysis for the Mean Values in Independent Groups (Student T test). The relationship between the variables was examined with Spearman correlation analysis. Data without normal distribution were given as median (minimum-maximum). Significance level was taken as $\mathrm{p}<0.05$.

\section{RESULTS}

A total of 100 individuals including 48 (48\%) male and 52 (52\%) female patients were included in the study. Demographic characteristics of the patients were shown on Table 1.

All participants knew their normal blood pressure values and had blood pressure device at home. The book reading rate was $50 \%(n=50)$ in our study group. Women read significantly more book compared to men $(p=0.045) .94(94 \%)$ of the patients in our study group were followed-up in state or training and research hospital. General characteristics of the patients were shown on Table 2.

We applied "Logistic Regression" analysis to see the possible collective effects of the factors we considered to be effective on systolic and diastolic blood pressures which constitute the main subject of our study. The effective factors on mean systolic blood pressure were shown and while "Physical Activity" and "Regular Book Reading" were significant in systolic blood pressure control $(p<0.05)$, "Being Married" was 


\begin{tabular}{|c|c|c|c|c|c|c|}
\hline \multirow{2}{*}{ Parameter } & \multicolumn{2}{|c|}{ Male } & \multicolumn{2}{|c|}{ Female } & \multicolumn{2}{|c|}{ General } \\
\hline & $\mathbf{n}$ & Mn \pm SD & $\mathbf{n}$ & Mn \pm SD & $\mathbf{n}$ & $M n \pm S D$ \\
\hline Age & 48 & $61.75 \pm 6.34$ & 52 & $45.98 \pm 4.73$ & 100 & $53.86 \pm 5.53$ \\
\hline Number of individuals in the family & 48 & $4.63 \pm 1.19$ & 52 & $3.92 \pm 1.15$ & 100 & $4.27 \pm 1.17$ \\
\hline Number of children & 48 & $2.81 \pm 0.93$ & 52 & $1.88 \pm 1.32$ & 100 & $2.34 \pm 1.12$ \\
\hline $\mathrm{BMI}$ & 48 & $28.38 \pm 1.97$ & 52 & $27.63 \pm 2.24$ & 100 & $28.0 \pm 2.10$ \\
\hline Education year & 48 & $8.88 \pm 1.95$ & 52 & $7.79 \pm 2.89$ & 100 & $8.33 \pm 2.42$ \\
\hline Monthly income & 48 & $2779 \pm 1.04$ & 52 & $2015 \pm 914$ & 100 & $2397 \pm 977$ \\
\hline HT duration & 48 & $8.31 \pm 2.82$ & 52 & $4.38 \pm 2.96$ & 100 & $6.34 \pm 2.89$ \\
\hline Number of medications taken & 48 & $2 \pm 0.61$ & 52 & $1.10 \pm 0.29$ & 100 & $1.55 \pm 0.45$ \\
\hline
\end{tabular}

again significant in systolic blood pressure control $(p<0.05)$. The relationship between "Being Married" and mean systolic blood pressure showed that the mean systolic blood pressure was under control in $59.5 \%$ and not under control in $40.5 \%$ of "Married" individuals while it was $100 \%(n=9)$ under control and $0 \%(\mathrm{n}=0)$ not under control in "Single individuals". The rate of individuals with mean systolic blood pressures under control was $29.4 \%$ and not under control in $70.6 \%$ in "Widows" $(p<0.001)$. Blood pressure control was better in single individuals. Statistical comparison of the characteristics and blood pressures of hypertension patients was shown on Table 3.

A significant effect of "Working Status" was detected $(p<0.05)$. "Years of Education" and "Monthly Income" were also detected as effective factors on mean systolic blood pressure $(p<0.05)$. While mean systolic blood pressure control was significant in individuals "Medication Compliance" $(p<0.05)$, "Being on Diet" was also found to be effective on mean systolic blood pressure control $(p<0.05)$. "Smoking Condition" and "Stress in the Working Environment" were found to be effective on mean systolic blood pressure control $(p<0.05)$. "Social Adaptation", "Avoidance of Substance", "Avoidance of Violence", "Family Status" and "Economic Condition" among social tendency factors effective on mean systolic blood pressure $(p<0.05)$, "Targets and Ideals" were not found to be effective.

Social adaptation, avoidance of substance, avoidance of violence, family status and economic condition among social tendencies factors were more significant in individuals with mean systolic blood pressures under control $(p<0.001)$. Targets and ideals among social tendencies factors were not found to be significant in individuals with mean systolic blood pressures under control $(p=0.084)$ (Table 4).

While factors effective on systolic blood pressure were effective on diastolic blood pressure, age, gender, number of individuals in the family, number of children, body mass index (BMI), hypertension duration and lack of regular measurement were also found to be effective $(p<0.05)$. Targets and ideals in addition to social adaptation, avoidance of substance, avoidance of violence, family status and economic condition among social tendency factors were also found to be effective on diastolic blood pressure $(p<0.05)$.
Based on the analysis of the relationship between "Age condition" and mean diastolic blood pressure, the average age of the patients with diastolic blood pressure under control was $52.95 \pm 10.029$ while it was $57.54 \pm 5.45$ in those with uncontrolled diastolic blood pressure and $p$ was found as 0.020 in their comparison.

Based on the analysis of the relationship between "Gender" and mean diastolic blood pressure, diastolic blood pressure was under control in 40 males (83.3\%) and in 47 (90.4\%) females. Diastolic blood pressure was not under control in 8 males $(16.7 \%)$ and in $5(9.6 \%)$ females $(p=0.073)$.

\section{DISCUSSION}

"Social Adaptation", "Avoidance of Substance Use", "Avoidance of Violence", "Family Status" and "Economic Status" among social tendency factors were observed to be better in patients with blood pressure under control.

Many studies on the subject made us consider that aerobic physical activity may be useful in preventing hypertension, its treatment and decreasing cardiovascular risk and mortality. ${ }^{[7]}$ A meta-analysis of randomized control studies showed that aerobic endurance training decreased resting systolic and diastolic blood pressure $3.0 / 2.4 \mathrm{mmHg}$ in general and 6.9/4.9 $\mathrm{mmHg}$ in hypertensive patients. ${ }^{[8]}$ Similarly, we observed a positive effect of "physical activity" and "regular exercise" on arterial blood pressure control in our study.

Blood pressure control was also better in individuals "Reading Books Regularly" in our study. A Chinese study showed that literacy and having information on hypertension had a significant effect on treatment and organization of training programs for literacy is suggested for rural areas. ${ }^{[9]}$ The direct relationship between hypertension follow-up and treatment and health-literacy was also clearly presented in a Turkish study. ${ }^{[10]}$ As the education level and income conditions may be better in individuals who regularly read books, we may consider that they have a more stabile psychological condition and this condition has a positive effect on blood pressure control. It is also possible that this group controls their diseases more regularly. 


\begin{tabular}{|c|c|c|c|c|c|c|c|}
\hline \multirow{2}{*}{ Parameter } & \multicolumn{2}{|c|}{ Male } & \multicolumn{2}{|c|}{ Female } & \multicolumn{2}{|c|}{ General } & \multirow[t]{2}{*}{$\mathbf{p}$} \\
\hline & $\mathbf{n}$ & n (\%) & $\mathbf{n}$ & n (\%) & $\mathbf{n}$ & n (\%) & \\
\hline Physically Active & 48 & $40(83.3)$ & 52 & $49(94.2)$ & 100 & $89(89)$ & 0.841 \\
\hline \multicolumn{8}{|l|}{ Regular Book Reading } \\
\hline Yes & 48 & $2(4.2)$ & 52 & $18(34.6)$ & 100 & $20(20)$ & \multirow{2}{*}{0.045} \\
\hline No & 48 & $46(95.8)$ & 52 & $34(65.4)$ & 100 & $80(80)$ & \\
\hline \multicolumn{8}{|l|}{ Marital Status } \\
\hline Married & 48 & $40(83.3)$ & 52 & $34(65.4)$ & 100 & $74(74)$ & \multirow{3}{*}{0.436} \\
\hline Single & 48 & $0(0)$ & 52 & $9(17.3)$ & 100 & $9(9)$ & \\
\hline Widow & 48 & $8(16.7)$ & 52 & $9(17.3)$ & 100 & $17(17)$ & \\
\hline \multicolumn{8}{|l|}{ Profession } \\
\hline Housewife & 48 & $0(0)$ & 52 & $18(34.6)$ & 100 & $18(18)$ & \multirow{6}{*}{0.653} \\
\hline Healthcare professional & 48 & $1(2.1)$ & 52 & $0(0)$ & 100 & $1(1)$ & \\
\hline Police & 48 & $9(18.8)$ & 52 & $0(0)$ & 100 & $9(9)$ & \\
\hline Trainer & 48 & $6(12.5)$ & 52 & $15(28.8)$ & 100 & $21(21)$ & \\
\hline Technical & 48 & $11(22.9)$ & 52 & $0(0)$ & 100 & $11(11)$ & \\
\hline Other & 48 & $21(43.7)$ & 52 & $19(36.5)$ & 100 & $40(40)$ & \\
\hline \multicolumn{8}{|l|}{ Working Status } \\
\hline Employed & 48 & $33(68.8)$ & 52 & $23(44.2)$ & 100 & $56(56)$ & \multirow{3}{*}{0.085} \\
\hline Retired & 48 & $14(29.2)$ & 52 & $1(1.9)$ & 100 & $15(15)$ & \\
\hline Unemployed & 48 & $1(2.1)$ & 52 & $28(53.8)$ & 100 & $29(29)$ & \\
\hline \multicolumn{8}{|l|}{ Regular Measurement } \\
\hline None & 48 & $0(0)$ & 52 & $1(1.9)$ & 100 & $1(1)$ & \\
\hline Once or twice a month & 48 & $29(60.4)$ & 52 & $37(71.2)$ & 100 & $66(66)$ & 0.706 \\
\hline Once or twice a week & 48 & $18(37.5)$ & 52 & $12(23.1)$ & 100 & $30(30)$ & 0.100 \\
\hline Every day & 48 & $1(2.1)$ & 52 & $2(3.8)$ & 100 & $3(3)$ & \\
\hline Medication Name Known & & & & & & & \\
\hline No & 48 & $1(2.1)$ & 52 & $21(40.4)$ & 100 & $22(22)$ & \\
\hline Some & 48 & $31(64.6)$ & 52 & $1(1.9)$ & 100 & $32(32)$ & 0.063 \\
\hline Yes & 48 & $16(33.3)$ & 52 & $30(57.7)$ & 100 & $46(46)$ & \\
\hline Follow-up Location & & & & & & & \\
\hline University & 48 & $3(6.3)$ & 52 & $2(3.8)$ & 100 & $5(5)$ & \\
\hline Training Hospital & 48 & $26(54.2)$ & 52 & $19(36.5)$ & 100 & $45(45)$ & 0.358 \\
\hline State Hospital & 48 & 19 (39.6) & 52 & $30(57.7)$ & 100 & $49(49)$ & 0.350 \\
\hline Family Health Center & 48 & $0(0)$ & 52 & $1(1.9)$ & 100 & $1(1)$ & \\
\hline Being On Diet & & & & & & & \\
\hline No & 48 & $3(6.3)$ & 52 & $18(34.6)$ & 100 & $21(21)$ & \\
\hline Sometimes & 48 & $40(83.3)$ & 52 & $21(40.4)$ & 100 & $61(61)$ & 0.674 \\
\hline Yes & 48 & $5(10,4)$ & 52 & $13(25)$ & 100 & $18(18)$ & \\
\hline Regular Exercise & & & & & & & \\
\hline None & 48 & $8(16.7)$ & 52 & $22(42.3)$ & 100 & $30(30)$ & \\
\hline Once or twice a week & 48 & 35 (72.9) & 52 & $15(28.8)$ & 100 & $50(50)$ & 0.083 \\
\hline More than three times a week & 48 & $5(10.4)$ & 52 & $15(28.8)$ & 100 & $20(20)$ & \\
\hline Smoking & & & & & & & \\
\hline No & 48 & $31(64.6)$ & 52 & $29(55.8)$ & 100 & $60(60)$ & 0.095 \\
\hline Yes & 48 & $17(35.4)$ & 52 & $23(44.2)$ & 100 & $40(40)$ & 5 \\
\hline Is the Environment Stressful & & & & & & & \\
\hline No & 48 & $32(66.7)$ & 52 & $24(46.2)$ & 100 & $56(56)$ & 0.064 \\
\hline Yes & 48 & $16(33.3)$ & 52 & $28(58.3)$ & 100 & $44(44)$ & 0.064 \\
\hline Chronic Disease & & & & & & & \\
\hline No & 48 & $44(91.7)$ & 52 & $49(94.2)$ & 100 & $93(93)$ & 0.643 \\
\hline Yes & 48 & $4(8.3)$ & 52 & $3(5.8)$ & 100 & $7(7)$ & 0.045 \\
\hline Systolic BP under Control & & & & & & & \\
\hline Yes & 48 & $28(58.3)$ & 52 & $30(57.7)$ & 100 & $58(58)$ & 0.653 \\
\hline No & 48 & $20(41.7)$ & 52 & $22(42.3)$ & 100 & $42(42)$ & \\
\hline Diastolic BP under Control & & & & & & & \\
\hline Yes & 48 & $40(83.3)$ & 52 & $47(90.4)$ & 100 & $87(87)$ & 0.527 \\
\hline No & 48 & $8(16.7)$ & 52 & $5(9.6)$ & 100 & $13(13)$ & 0.521 \\
\hline Regular Doctor Control & & & & & & & \\
\hline Never & 48 & $1(2.1)$ & 52 & $3(5.8)$ & 100 & $4(4)$ & \\
\hline Sometimes & 48 & $24(50)$ & 52 & $39(75)$ & 100 & $63(63)$ & 0.073 \\
\hline Regular & 48 & $23(47.9)$ & 52 & $10(19.2)$ & 100 & $33(33)$ & \\
\hline
\end{tabular}




\begin{tabular}{|c|c|c|c|c|c|}
\hline \multirow{2}{*}{ Parameter } & \multirow{2}{*}{ n (\%) } & \multicolumn{2}{|c|}{ Systolic BP } & \multicolumn{2}{|c|}{ Diastolic BP } \\
\hline & & OR & $\mathbf{p}$ & OR & $\mathbf{p}$ \\
\hline Physically Active & $89(89)$ & 4.955 & 0.026 & 56.640 & $<0.001$ \\
\hline \multicolumn{6}{|l|}{ Regular Book Reading } \\
\hline Yes & $20(20)$ & \multirow[t]{2}{*}{20.000} & \multirow[t]{2}{*}{$<0,001$} & \multirow[t]{2}{*}{20.000} & \multirow[t]{2}{*}{$<0.001$} \\
\hline No & $80(80)$ & & & & \\
\hline \multicolumn{6}{|l|}{ Marital Status } \\
\hline Married & $74(74)$ & \multirow{3}{*}{11.649} & \multirow{3}{*}{0.003} & \multirow{3}{*}{64.351} & \multirow{3}{*}{$<0,001$} \\
\hline Single & $9(9)$ & & & & \\
\hline Widow & $17(17)$ & & & & \\
\hline \multicolumn{6}{|l|}{ Profession } \\
\hline Housewife & $18(18)$ & & & & \\
\hline Healthcare professional & $1(1)$ & & & & \\
\hline Police & $9(9)$ & 0.179 & 0.728 & 21.258 & $<0.001$ \\
\hline Trainer & $21(21)$ & & & & \\
\hline Technical & $11(11)$ & & & & \\
\hline Other & $40(40)$ & & & & \\
\hline Working Status & & & & & \\
\hline Employed & $56(56)$ & & & & \\
\hline Retired & $15(15)$ & 14.067 & 0.001 & 37.838 & $<0.001$ \\
\hline Unemployed & $29(29)$ & & & & \\
\hline Regular Measurement & & & & & \\
\hline Never & $1(1)$ & & & & \\
\hline Once or twice a month & $66(66)$ & 3.376 & 0.337 & 52.261 & $<0.001$ \\
\hline Once or twice a week & $30(30)$ & & & & \\
\hline Every day & $3(3)$ & & & & \\
\hline Medication Name Known & & & & & \\
\hline No & $22(22)$ & & & & \\
\hline Some & $32(32)$ & 9.846 & 0.002 & 18.615 & $<0.001$ \\
\hline Yes & $46(46)$ & & & & \\
\hline Follow-up Location & & & & & \\
\hline University & $5(5)$ & & & & \\
\hline Training Hospital & $45(45)$ & 2.599 & 0.118 & 49.539 & $<0.001$ \\
\hline State Hospital & 49 (49) & & & & \\
\hline Family Health Center & $1(1)$ & & & & \\
\hline Being On Diet & & & & & \\
\hline No & $21(21)$ & & & & \\
\hline Sometimes & $61(61)$ & 14.403 & 0.001 & 45.934 & $<0.001$ \\
\hline Yes & $18(18)$ & & & & \\
\hline Regular Exercise & & & & & \\
\hline Never & $30(30)$ & & & & \\
\hline Once or twice a week & $50(50)$ & 13.370 & 0.001 & 39.253 & $<0.001$ \\
\hline More than three times a week & $20(20)$ & & & & \\
\hline Smoking & & & & & \\
\hline No & $60(60)$ & 13.067 & $<0,001$ & 26.667 & $<0.001$ \\
\hline Yes & $40(40)$ & & & & \\
\hline Is the Environment Stressful & & & & & \\
\hline No & $56(56)$ & 12.071 & 0.001 & 37.786 & $<0.001$ \\
\hline Yes & $44(44)$ & & & & \\
\hline Chronic Disease & & & & & \\
\hline No & $93(93)$ & 1.333 & 0.248 & 21.333 & $<0.001$ \\
\hline Yes & $7(7)$ & & & & \\
\hline Systolic BP under Control & & & & & \\
\hline Yes & $58(58)$ & 2.492 & 0.127 & 18.468 & $<0.001$ \\
\hline No & $42(42)$ & & & & \\
\hline Diastolic BP under Control & & & & & \\
\hline Yes & $87(87)$ & 3.245 & 0.284 & 16.397 & $<0.001$ \\
\hline No & $13(13)$ & & & & \\
\hline Regular Doctor Control & & & & & \\
\hline Never & $4(4)$ & 7571 & & 25730 & $<0001$ \\
\hline Sometimes & $63(63)$ & $7.5 / 1$ & 0.023 & 25.130 & $<0.001$ \\
\hline Regular & $33(33)$ & & & & \\
\hline
\end{tabular}

Table 4. The Relationship between Fatih Social Tendencies Scale factors and mean systolic blood pressure

\begin{tabular}{llcccc} 
& $\begin{array}{l}\text { Mean Systolic } \\
\text { Blood Pressure } \\
\text { Values }\end{array}$ & n & Mean & SD & p \\
\hline Social & Controlled & 58 & 4.2011 & .29905 & $<0.001$ \\
Adaptation & Uncontrolled & 42 & 3.4127 & .43436 & \\
Avoiding & Controlled & 58 & 3.8506 & .72325 & $<0.001$ \\
Substance Use & Uncontrolled & 42 & 2.5714 & .59939 & \\
Avoiding & Controlled & 58 & 4.1782 & .89881 & $<0.001$ \\
Violence & Uncontrolled & 42 & 1.8968 & .55332 & \\
Familial Status & Controlled & 58 & 4.1149 & .51224 & $<0.001$ \\
& Uncontrolled & 42 & 2.4643 & .46640 & \\
Economic & Controlled & 58 & 2.7931 & .73303 & $<0.001$ \\
Condition & Uncontrolled & 42 & 2.1111 & .42717 & \\
Targets and & Controlled & 58 & 4.8060 & .37182 & 0.084 \\
Ideals & Uncontrolled & 42 & 4.7560 & .44341 & 0.084 \\
\hline *Student T test, SD: Standard Deviation & & & & \\
\hline
\end{tabular}

A Swedish study on hypertension and health-related life quality covering 8000 participants showed that the blood pressure control was better in single and married individuals compared to widows. ${ }^{[1]}$ We observed in our study that the blood pressure was in control in "Most of the Married Individuals", "All Singles" but only $29.4 \%$ of the widows. Formation of unexpected condition such as death of a spouse or divorce in widows may cause some psychiatric changes and anxiety in the individuals.

A study made in North Carolina showed that the group over 65 years of age and the individuals with a lower education level had less information (information acquired through curiosity, not without any obligation). ${ }^{[12]}$ Information level of individuals over the age of 60 and the individuals with a low education level was found lower in another study made in USA. Low information level is a factor negatively affecting blood pressure control. ${ }^{[13]}$ Although we could not find any study directly on years of education in literature, we observed in our study that blood pressure control was positively affected as "Years of Education" increased.

A study made in China detected low socioeconomic level as a factor negatively affecting blood pressure control. ${ }^{[14]}$ Our study detected better blood pressure control in individuals with "Highly Monthly Income". Socioeconomic level is among the most important factors determining the life style and thus the psychological condition of the patient.

The blood pressure controls were better in "Employed" and "Retired" individuals compared to "Unemployed" individuals in our study. No similar studies were found in literature but retirement salary and less or no financial concerns of retired individuals compared to unemployed individuals may explain why their controls are better than unemployed individuals. Again, less or no financial concern of employed individuals may explain why they have better blood pressure controls financial concerns constitute an anxietycausing factor. Primary and secondary HT risk increases with increasing age. ${ }^{[15]}$ 
Medication compliance had a positive effect on blood pressure control as expected. This data supported by many other previous studies is not shocking. ${ }^{[14]}$

Blood pressure control was better in individuals having "Regular Doctor Control" and "Occasional Doctor Control" compared to those having "No Doctor Control" in our study. Previous studies also showed regular doctor control as an important factor affecting blood pressure control. ${ }^{[16]}$

Factors such as being on diet, smoking, regular exercise and stress condition in the environment were detected as significant factors in blood pressure control in a study made in Ankara. ${ }^{[17]}$ Our study showed that the blood pressures of "Individuals on Diet" were under more control and the blood pressures of individuals making exercise at least once or twice a week were under control and no smoking and unstressed environment positively affected blood pressure control. Previous studies had also detected that these factors had a significant role in blood pressure control. ${ }^{[18,19]}$

There was a positive relationship between blood pressure control and the positive nature of "Social Adaptation", "Avoidance of Substance", "Economic Condition", "Family Status" and "Avoidance of Violence" of Social Tendencies scale we used in our study. We found no studies on this subject in literature. Psychological factors are known to be effective on blood pressure. The mentioned factors can be considered to have a significant effect on psychology. These factors may be a demonstrator of the stabile psychology of an individual. It may also be considered that the psychologies of the individuals with good blood pressure control are positively affected in this regard. Thus, this finding will make an important contribution to the literature as it concretely presents the importance of psychology and point of view in blood pressure control. This finding also shows the necessity of providing psychological support to the patients.

\section{CONCLUSION}

Factors such as physical activity, regular exercise, regular book reading, marital status, years of education, working status, medication compliance, regular doctor visits, being on diet and smoking were found to be effective on blood pressure control in our study. Social adaptation, avoidance of substance, avoidance of violence, family status and economic condition factors of Fatih Social Tendencies scale we used are also effective on blood pressure control in psychological terms. Supporting the patient through considering the factors mentioned above in blood pressure follow-up and giving the required information and training on this subject would make a great contribution to the patients in terms of blood pressure control. This can only be achieved by providing the opportunity for doctors to examine patients in sufficient time.

\section{ETHICAL DECLARATIONS}

Ethics Committee Approval: Consent no 5166 was taken from Ankara Training and Research Hospital Ethics Board in the meeting no 0617 dated 11.11.2015 before starting our study.

Informed Consent: All patients signed the free and informed consent form.

Referee Evaluation Process: Externally peer-reviewed.

Conflict of Interest Statement: The authors have no conflicts of interest to declare.

Financial Disclosure: The authors declared that this study has received no financial support.

Author Contributions: All of the authors declare that they have all participated in the design, execution, and analysis of the paper, and that they have approved the final version.

\section{REFERENCES}

1. Chowdhury EK, ASPREE Investigator Group. Impact of the 2017 American Heart Association and American College of Cardiology hypertension guideline in aged individuals. J Hypertens. 2020;38(12):2527-36.

2. Altun B, Arici M, Nergizoglu G, et al. Prevalence, awareness, treatment and control of Hypertension, in Turkey (the PatenT study) in 2003. J Hypertens 2005;23:1817-23.

3. Soydan İ. Hipertansiyon ile ilgili TEKHARF çalışması verileri ve yorumu In: Onat A (ed). Türk Erişkinlerde Kalp Sağlığı (TEKHARF). İstanbul: Argos iletişim, 2003; 60-71.

4. Ulusal Hastalık Yükü ve Maliyet-Etkililik Projesi Final Raporu, Ankara: T.C. Sağlık Bakanlığı, Refik Saydam Hıfzıssıhha Mektebi Müdürlüğü ve Başkent Üniversitesi Yayını; 2004. Pages 33-34.

5. T.C. Sağlık Bakanlığı, Türkiye Sağlık Okuryazarlığı Ölçekleri Güvenilirlik ve Geçerlilik Çalışması. https://sbu.saglik.gov.tr/Ekutuphane/Home/ GetDocument/166 Erişim tarihi: 22.09.2020.

6. James P, Oparil S, Carter B, et al. 2014 Evidence-based guideline for the management of high blood pressure in adults report from the panel members appointed to the Eighth Joint National Committee (JNC 8). JAMA 2014;311:507-20.

7. Tekin O, Özkara A, Cebeci S ve ark. 11-20 Yaş Öğrencilerde Sosyal Eğilimler Anketi. Yeni Tıp Derg 2007;24:198-204.

8. Fagard RH. Physical activity, fitness and mortality. Journal of Hypertension 2012;30:1310-12.

9. Cornelissen VA, Fagard RH. Effects of endurance training on blood pressure, blood pressure-regulating mechanisms, and cardiovascular risk factors. Hypertension 2005;46: 667-75.

10. Li X, Ning N, Hao Y, et al. Health Literacy in Rural Areas of China: Hypertension Knowledge Survey. International J Environment Res Public Health 2013;10(3):1125-38.

11. Bardage C, Isacson GL. Hypertension and health-related quality of life: an epidemiological study in Sweden. J Clin Epidemiol 2001;54:172-81.

12. Viera AJ, Cohen LW, Mitchell CM, et al. High blood pressure knowledge among primary care patients with known hypertension: a North Carolina Family Medicine Research Network (NC-FM-RN) study. J Am Board Fam Med 2008;21:300-8.

13. Sanne S, Muntner P, Kawasaki L, et al. Hypertension knowledge among patients from an urban clinic. Ethnicity Dis 2008;18:42.

14. Li W, Jiang $X, M a ~ H$, et al. Awareness, treatment and control of hypertension in patients attending hospital clinics in China. J Hypertens 2003;21:1191-97.

15. Cohen L, Curhan GC, Forman JP. Influence of age on the association between lifestyle factors and risk of hypertension. J Am Soc Hypertens. 2012;6:284-90. 
16. Clark LT, Afflu E. Antihypertensive therapy: factors affecting medication compliance and blood pressure control. Am J Manager Care 1995;1:28994.

17. Çöl M, Özdemir O, Ocaktan ME. Park Sağlık Ocağı bölgesindeki 35 yaş üstü hipertansiflerde tedavi kontrol durumları ve davranışsal faktörler. Ankara Üniversitesi Tıp Fakültesi Mecmuası 2006;59:144-50.

18. Oliveria Susan A,Chen RS, McCarthy BD, et al. Hypertension knowledge, awareness, and attitudes in a hypertensive population. J Gen Intern Med 2005;20:219-25.

19. Watson K, Jamerson K. Therapeutic lifestyle changes for hypertension and cardiovascular risk reduction. J Clin Hypertens 2003;5:32-7. 